\title{
DETECTION OF SOME PESTICIDES RESIDUES IN RAW MILK
}

\author{
EL ASUOTY, M.S. ${ }^{1}$; FAYZA, A. EL TEDAWY ${ }^{2}$; AMANY, A. SALLAM ${ }^{2}$ and \\ FAYZA, A. SDEEK ${ }^{3}$ \\ ${ }^{1}$ Researcher of Food Hygiene, Animal Health Research Institute, Damanhour Branch, Egypt. \\ ${ }^{2}$ Senior Researcher of Biochemistry, Animal Health Research Institute, Damanhour Branch, Egypt. \\ ${ }^{3}$ Researcher of Pesticides, Department of Pesticides Residues and Environment Pollution., Central Agriculture \\ Pesticides Laboratory, Dokki, Egypt.
}

Received: 16 February 2017; Accepted: 20 March 2017

\begin{abstract}
Milk could be contaminated with pesticides from fodder, soil and ingestion of insecticides due to widespread application of pesticides in agriculture. Therefore, the present study was conducted to determine the concentration of organochlorine (OC), synthetic pyrethroids and organophosphorus (OP) pesticide, using chromatography mass spectroscopy in milk samples collected from El-Beheria governorate, Egypt. The obtained results revealed that OCPs Hexachlorocyclohexane isomers Alph, gama \&Delta (HCHs), Heptachlorepoxide, Aldrin, $\Upsilon$ - chlordane, Dieldrin, DDE, DDD and Methoxychlor and were monitored at percent of 3.3, 13.3, 83.3, 93.3, 3.3, 13.3, 23.3, 60, 70 and $83.3 \%$ respectively, in the examined milk samples while Heptachlor, Endosulfan, Endrin and DDT were not detected in the same samples. Synthetics pyrethroids including (cypermethrin, deltmethrin, Fenvaluate, Lambda_cyhalothrin and Permethrin) were detected at 60, 40, 50, 56.7 and $60 \%$ of examined samples while, Fenopropathrin was not detected in the examined milk samples. Concerning OP pesticides, all examined milk samples were contaminated with Diazinon 30 (100\%), while Chlopyrifos was detected in only one sample $1(3.3 \%)$, other OP pesticides were not detected in the examined samples. This study investigated only pesticides residues and illustrated the risks of pesticides residues exposure that threaten consumer health. Thus, monitoring survey of pesticide residues in milk is necessary to safeguard consumer health.
\end{abstract}

Key words: organochlorine, Pyrethroid, organophosphorus pesticides, raw milk, Chromatography mass spectroscopy.

\section{INTRODUCTION}

Milk is an ideal fluid to dissolve environmental organic pollutants such as pesticide residues since most of them have lipophilic properties (Kampire et al., 2011). Thus, milk is used as an indicator for determining the persistence of organic pollutants. The term pesticide coversa widerange of compounds including insecticides, herbicides, rodenticides, and others. Among these, organochlorine (OC) insecticides, used successfully in controlling a number of diseases, suchas malaria, and typhus. The introduction of other synthetic insecticides, i.e., organophosphate (OP) insecticides in pyrethroids and herbicides contributed greatly in pest control and agricultural output (Akhtar et al., 2009).

Corresponding author: Dr. EL ASUOTY, M.S.

E-mail address: mido_15158@hotmail.com

Present address: Researcher of Food Hygiene, Animal Health

Research Institute, Damanhour Branch, Egypt
The contamination of milk is considered as one of the main dangerous issues in the last few years. Milk can be contaminated by pesticide residues such as organochlorine (OC), organophosphorous (OP) pesticides as well as pyrethroids pesticides (Fontcuberta et al., 2008). The presence of pesticide residues in milk is considered a public health concern because milk and dairy products are widely consumed by infants, children, and adults. Pesticide residues in milk originate from contaminated feed, grass or corn silage, and direct application of pesticides on dairy cattle. Because humans are the last link in the food chain, they consume the highest levels of these compounds. Food products particularly milk and dairy products are the primary immediate sources of OC and OP pesticide intake in the general population (Johansen et al., 2004).

Organophosphorus (OP) pesticides are esters, amides, or thiol derivatives of phosphoric acid. OP pesticides are easily hydrolyzed and therefore, do not persist in the environment. However, their toxicity (high or moderate) and the possibility of their accumulation especially fat-soluble OPs in animal tissues, milk, and 
eggs pose risks for human health (Fagnani et al., 2011).

Organochlorine (OC) compounds are lipophilic and metabolized very little in living organisms. Hence, environmental exposure to these compounds results in their accumulation and persistence in fat tissue (Falandysz et al., 2004). Moreover, OC pesticides undergo biomagnification through the food chain causing a chronic toxicity after long- term exposure (Borga et al., 2001). The chronic effects of pesticides from contaminated food on human health are not well defined, but there is increasing evidence of carcinogenicity and genotoxicity, as well as disruption of hormonal functions (Ledoux, 2011).

Organophosphorus and pyrethroids pesticide residues are widely used in agriculture and in animal husbandry in Egypt while, the OC pesticides have been banned a long time ago. OP and pyrethroids pesticides are less persistent than OC pesticide residues in environment. In order to ensure the safety of milk for the consumer, it is very important to know the pesticide residual levels and compared with recommended toxicological criteria such as maximum residue limit (MRL) and the acceptable daily intake (ADI). Legislation in the European Union has established MRLs of $40 \mathrm{ng} / \mathrm{g}$ and $0.8 \mathrm{ng} / \mathrm{g}$ for the target OC pesticides dichloro-diphenyltrichloroethane and endrin, respectively, in milk. The MRL for chlorpyrifos is $10 \mathrm{ng} / \mathrm{g}$ (EU, 2007).

To aid in the protection of consumer health and elimination of unsafe food, as well as to be comply with the requirements of the international food standard. This study was conducted to determine the levels of several OC, pyrethroids and OP pesticide residues in raw milk samples collected from various regions of El-Beheriagovernorates.

\section{MATERIALS AND METHODS}

\section{Samples:}

A total of 30 fresh raw milk samples (500 $\mathrm{ml}$ of each) were collected from different supermarkets at ElBeheria Governorate, Egypt during the period from April 2016 to May 2016. Each sample was received in glass bottles and tested for heat treatment (storch test) according to (Lampert 1975), then samples was stored at $-20^{\circ} \mathrm{C}$ until for detection of pesticides residues.

\section{Pesticide residues analysis according to Lehotay et al. (2005):}

All reagents and chemical used in this study were of analytical grade. Pesticide standards were used in monitoring survey contained the following OCPs: Hexachlorocyclohexane $(\mathrm{HCH})(\alpha-, \beta-, \gamma-\mathrm{HCH}$ isomers), heptachlor and its metabolite (heptachlor epoxide), Aldrin, endrin, $\Upsilon$-chlordane, dichlorodiphenyltrichloroethane ( $p p^{\prime}$-DDT) and its metabolites (pp'-DDE and pp'-DDD) and methoxychlor. While, OP pesticide standard included: ethoprophos, phorate, diazinon, dimethoate, pirimiphos-methyl, chlorpyrifos, malathion, prothiophos, fenamiphos, ethion and triazophos. In addition, the synthetic pyrethroids standard was permethrin, cypermethrin, deltamethrin, Fenopropathrin, Fenvaluate and Lambda_cyhalothrin.

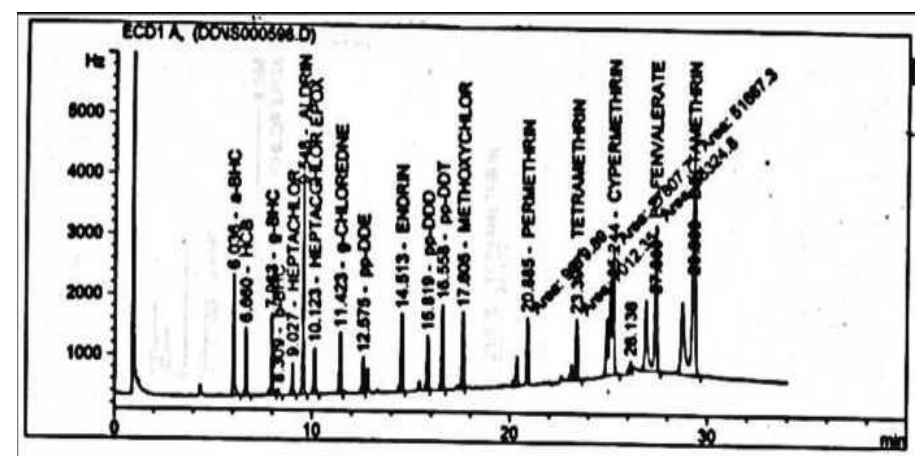

Fig. Organochlorine and pyrethroids mixture reference standard chromatogram

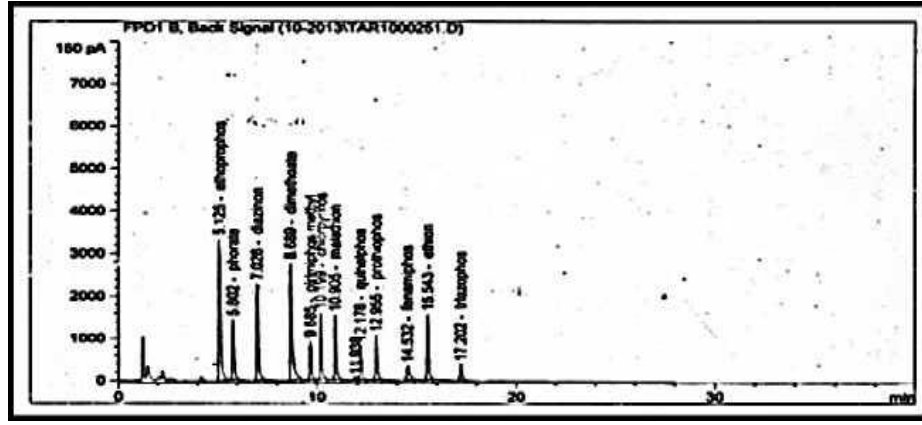

Fig. Organophosphorus reference standard chromatogram 


\section{Instrument Conditions according to Lehotay et al. (2005):}

Determination of $\mathrm{OC}$ and pyrethroid pesticide residues were performed on Hewlett Packared GC model $6890 \mathrm{~N}$ equipped with a Ni63- electron capture detector (GC-ECD). GC-ECD had a capillary column PAS-5 (30 m length x $0.32 \mathrm{~mm}$ internal diameter $\mathrm{x}$ $0.25 \mu \mathrm{m}$ film thickness). Injector and detector temperature program were $300^{\circ} \mathrm{C}$ for $2 \mathrm{~min}$, raised at the $3^{\circ} \mathrm{C}$ min- 1 and then held at $260^{\circ} \mathrm{C}$ for $15 \mathrm{~min}$. The carrier gas was $\mathrm{N} 2$ at a flow rate of $4 \mathrm{ml} / \mathrm{min}$. As for OPPs the same model of gas chromatograph was used and fitted with a flame photometric detector (FPD) with phosphorus filter. It attached to a fused silica capillary column PAS-1701 (30 min length $\mathrm{x} 0.32$ $\mathrm{mm}$ internal diameter $\mathrm{x} 0.25 \mu \mathrm{m}$ film thickness). The Injector and detector temperature program were 240 ${ }^{\circ} \mathrm{C}$ and $250{ }^{\circ} \mathrm{C}$, initial oven temperature, $200{ }^{\circ} \mathrm{C}$ for 2 min, raised at $6{ }^{\circ} \mathrm{C}$ min- 1 then held at $250{ }^{\circ} \mathrm{C}$ for 15 min. The carrier gas was nitrogen at $3 \mathrm{ml} \mathrm{min}-1$; hydrogen and air were used for combustion in 75 and $100 \mathrm{ml}$ min-1, respectively.

\section{Extraction and clean- up:}

Prior to extraction, all glassware used in this study were washed with soap and water, followed by distilled water and acetone and finally heated at 220 ${ }^{\circ} \mathrm{C}$ in oven till use. The technique adopted to extract and clean-up multi-pesticide residues from milk samples was one used in details by Battu et al. (2004)

Recovery analysis was carried out on samples spiked with multi-pesticide residues standards. Extraction and clean- up were carried out on spiked samples as proposed technique. Blank analysis also has been carried out to check the interference in samples. Detected pesticide residues in all examined milk samples were calculated as ppm.

\section{RESULTS}

Table 1: Organochlorinepesticide residues (ppm whole milk basis) in examined milk samples.

\begin{tabular}{|c|c|c|c|c|c|c|c|c|}
\hline \multirow{2}{*}{ NO } & \multirow{2}{*}{ Detected Pesticides } & \multicolumn{2}{|c|}{ Incidence } & \multirow{2}{*}{ Minimum } & \multirow{2}{*}{ Maximum } & \multirow{2}{*}{ Mean \pm SEM } & \multicolumn{2}{|c|}{ MRLs } \\
\hline & & NO & $\%$ & & & & $\begin{array}{c}\text { FAO/WHO } \\
(2013)\end{array}$ & EU (2014) \\
\hline 1 & Alpha_HCH & 1 & 3.3 & 0.00 & 0.0011 & $0.00055 \pm 0.0005$ & N.E & 0.004 \\
\hline 2 & gama_HCH & 4 & 13.3 & 0.00020 & 0.00300 & $0.000927 \pm 0.00069$ & N.E & 0.001 \\
\hline 3 & Delta_HCH & 25 & 83.3 & 0.0006 & 1.4400 & $0.182976 \pm 0.07008$ & N.E & 0.003 \\
\hline 4 & Heptachlor & 0.00 & 0.00 & 0.00 & 0.00 & 0.00 & & \\
\hline 5 & Heptachlorepoxide & 28 & 93.3 & 0.0002 & 0.0160 & $0.00204 \pm 0.0005$ & & \\
\hline 6 & Aldrin & 1 & 3.3 & 0.00 & 0.0001 & $0.00005 \pm 0.00005$ & 0.006 & 0.006 \\
\hline 7 & Gama_chlordan & 4 & 13.3 & 0.0008 & 0.0010 & $0.00095 \pm 0.00005$ & 0.002 & 0.002 \\
\hline 8 & Endosulfan & 0.00 & 0.00 & 0.00 & 0.00 & 0.00 & 0.01 & 0.05 \\
\hline 9 & Dieldrin & 7 & 23.3 & 0.0010 & 0.0030 & $0.00186 \pm 0.00034$ & 0.006 & 0.006 \\
\hline 10 & Endrin & 0.00 & 0.00 & 0.00 & 0.00 & 0.00 & N.E & 0.0008 \\
\hline 11 & PP_DDE & 18 & 60 & 0.0001 & 0.0060 & $0.00143 \pm 0.00042$ & & \\
\hline 12 & PP_DDD & 21 & 70 & 0.00010 & 0.00200 & $0.00075 \pm 0.000092$ & Sum $=0.02$ & Sum $=0.04$ \\
\hline 13 & PP_DDT & 0.00 & 0.00 & 0.00 & 0.00 & 0.00 & & \\
\hline 14 & Methoxychlor & 25 & 83.3 & 0.01 & 0.39 & $0.1424 \pm 0.0244$ & N.E & 0.01 \\
\hline
\end{tabular}

N.E: Not Established 


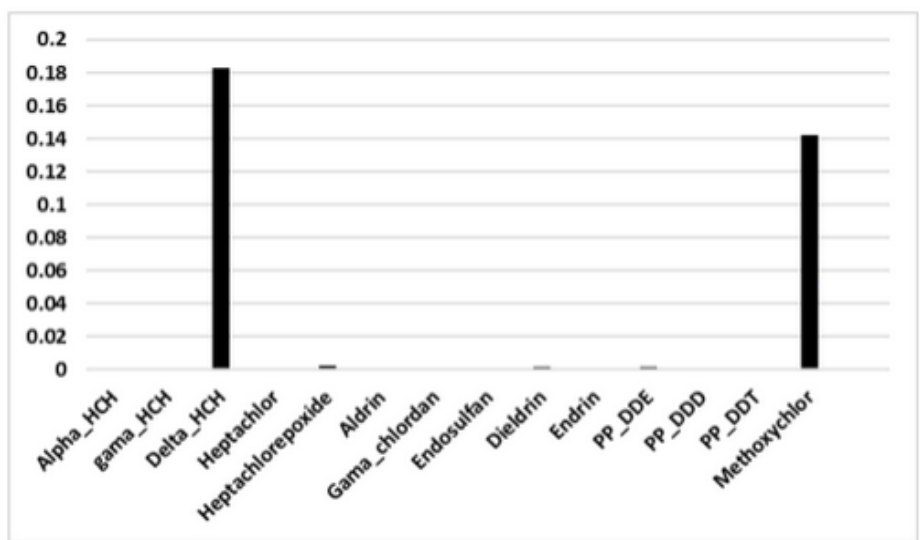

Fig. 1: Mean values of different organochlorine pesticides detected in examined milk samples

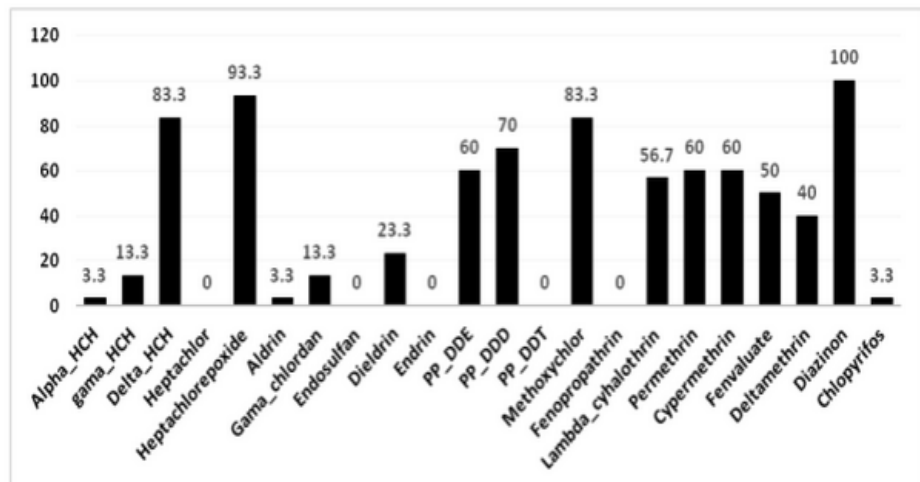

Fig. 2: Incidence of pesticides residues in analyzed milk samples.

Table 2: Pyrethroid pesticide residues (ppm whole milk basis) in examined milk samples.

\begin{tabular}{|c|c|c|c|c|c|c|c|c|}
\hline \multirow[b]{2}{*}{ NO } & \multirow[b]{2}{*}{ Detected Pesticides } & \multicolumn{2}{|c|}{ Incidence } & \multirow[b]{2}{*}{ Minimum } & \multirow[b]{2}{*}{ Maximum } & \multirow[b]{2}{*}{ Mean \pm SEM } & \multicolumn{2}{|c|}{ MRLs } \\
\hline & & No & $\%$ & & & & $\begin{array}{c}\text { FAO/WHO } \\
(2013)\end{array}$ & $\begin{array}{c}\mathbf{E U} \\
(2014)\end{array}$ \\
\hline 1 & Cypermethrin & 18 & 60 & 0.002 & 0.050 & $0.0253 \pm 0.0040$ & 0.05 & 0.05 \\
\hline 2 & Deltamethrin & 12 & 40 & 0.01 & 0.06 & $0.0417 \pm 0.0041$ & 0.05 & 0.05 \\
\hline 3 & Fenopropathrin & 0.00 & 0.00 & 0.00 & 0.00 & 0.00 & 0.01 & N.E \\
\hline 4 & Fenvaluate & 15 & 50 & 0.003 & 0.080 & $0.0242 \pm 0.0065$ & 0.01 & N.E \\
\hline 5 & Lambda_cyhalothrin & 17 & 56.7 & 0.002 & 0.065 & $0.0156 \pm 0.0044$ & N.E & 0.05 \\
\hline 6 & Permethrin & 18 & 60 & 0.002 & 0.060 & $0.0263 \pm 0.0052$ & N.E & 0.05 \\
\hline
\end{tabular}

N.E: Not Established

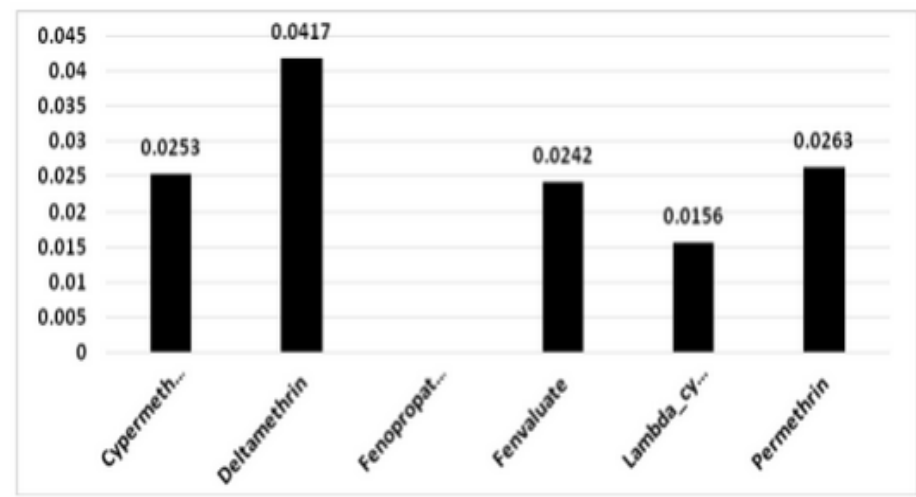

Fig. 3: The mean values of different Pyrethroid pesticides detected in examined milk samples. 
Table 3: Organophosphorus pesticide residues (ppm whole milk basis) in examined samples.

\begin{tabular}{|c|c|c|c|c|c|c|c|c|}
\hline \multirow[b]{2}{*}{ NO } & \multirow[b]{2}{*}{ Detected Pesticides } & \multicolumn{2}{|c|}{ Incidence } & \multirow[b]{2}{*}{ Minimum } & \multirow[b]{2}{*}{ Maximum } & \multirow[b]{2}{*}{ Mean \pm SEM } & \multicolumn{2}{|c|}{ MRLs } \\
\hline & & No & $\%$ & & & & $\begin{array}{c}\text { FAO/WHO } \\
(2013)\end{array}$ & $\begin{array}{c}\text { EU } \\
(2014)\end{array}$ \\
\hline 1 & Ethoprophos & 0.00 & 0.00 & 0.00 & 0.00 & 0.00 & & \\
\hline 2 & Phorate & 0.00 & 0.00 & 0.00 & 0.00 & 0.00 & & \\
\hline 3 & Diazinon & 30 & 100 & 0.01 & 0.04 & $0.0183 \pm 0.0017$ & 0.02 & 0.02 \\
\hline 4 & Dimethoate & 0.00 & 0.00 & 0.00 & 0.00 & 0.00 & & \\
\hline 5 & Primiphosmethyle & 0.00 & 0.00 & 0.00 & 0.00 & 0.00 & & \\
\hline 6 & Chlopyrifos & 1 & 3.3 & 0.00 & 0.62 & $0.3100 \pm 0.0017$ & 0.02 & 0.01 \\
\hline 7 & Malathion & 0.00 & 0.00 & 0.00 & 0.00 & 0.00 & & \\
\hline 8 & Quinelphos & 0.00 & 0.00 & 0.00 & 0.00 & 0.00 & & \\
\hline 9 & Prothiophos & 0.00 & 0.00 & 0.00 & 0.00 & 0.00 & & \\
\hline 10 & Fenamiphos & 0.00 & 0.00 & 0.00 & 0.00 & 0.00 & & \\
\hline 11 & Ethion & 0.00 & 0.00 & 0.00 & 0.00 & 0.00 & & \\
\hline 12 & Triazophos & 0.00 & 0.00 & 0.00 & 0.00 & 0.00 & & \\
\hline
\end{tabular}

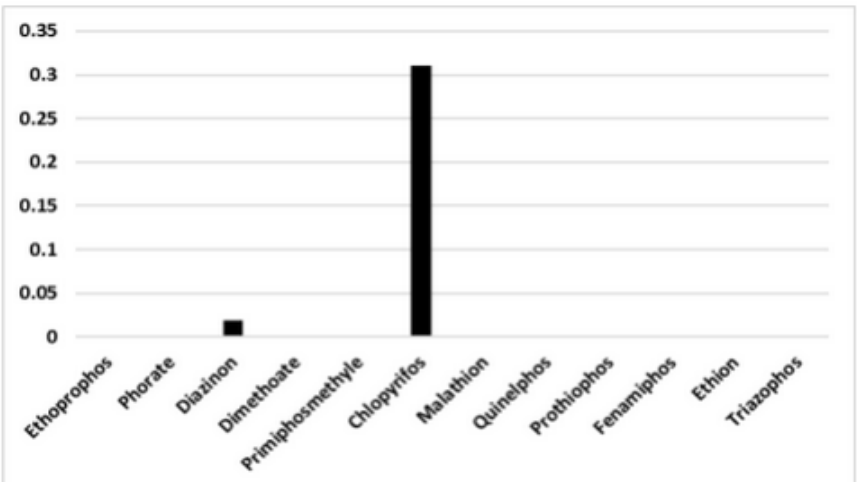

Fig. 4: The mean values of different organophosphorus pesticides detected in examined milk samples

\section{DISCUSSION}

Data in all Tables represented the detected pesticides residues including (OC, OP and Pyrethroids), arithmetic means \pm standard errors and their minimum and maximum residual levels compared with corresponding maximum residue limits (MRLs) recommend by the Codex Alimentarius Commission (FAO/ WHO, 2013) and (European Union (EU), 2014).

Data in Table 1 and Fig 1 reflect that all analyzed raw milk samples were contaminated with OCP residues except heptachlor, Endosulfan, Endrin and DDT. The mostly detected OCP were heptachlor epoxide $93.3 \%$ followed by Delta $\mathrm{HCH}$ and Methoxychlor $(83.3 \%$ for both) at mean concentrations of 0.00204, 0.182976 and $0.1424 \mathrm{ppm}$, respectively. pp'-DDE and pp'-DDD was detected 60 and $70 \%$ of the samples. With mean values 0.00143 and 0.00075 ppm, respectively, while pp'-DDT was not detected in the examined milk samples. As for $\mathrm{HCH}$ and its metabolites, $\alpha-\mathrm{HCH}$ was detected in one sample only with percent $(3.3 \%)$ while $\Upsilon-\mathrm{HCH}$ and Delta HCD were detected in 4 and 25 samples with a percent
(13.3 and $83.3 \%)$, While the average concentration were as this follows: $\alpha-\mathrm{HCH}(0.00055), \Upsilon-\mathrm{HCH}$ (0.000927) and Delta HCH (0.182976) ppm. Endrin not detected in examined milk samples while Aldrin and Dieldrin were identified in one sample $(3.3 \%)$ and 7 samples $(23.3 \%)$ at a mean concentrations of 0.0005 and $0.00186 \mathrm{ppm}$, respectively. $\Upsilon$ - chlordan were detected in 4 milk samples $(13.3 \%)$ with mean value $0.00095 \mathrm{ppm}$. Endosulfan was not detected in the examined milk samples. Levels of OCP residues detected $(\alpha-\mathrm{HCH}, \Upsilon-\mathrm{HCH}$, Delta $\mathrm{HCH}$ and Methoxychlor) were above their respective while, other OCP residues blow their respective MRLs recommended by $\mathrm{FAO} / \mathrm{WHO}$ and European Union legislation.

The technical-grade $\mathrm{HCH}$ is a mixture of different isomers $(\alpha, \beta, \Upsilon$ isomers $) ; \alpha-\mathrm{HCH}, \Upsilon-\mathrm{HCH}$, Delta $\mathrm{HCH}$ were detected in 1, 4, 25 samples at percent 3.3, 13.3 and $83.3 \%$, while Battu et al. (2004) could detect $\Upsilon-\mathrm{HCH}$ (lindane) in $40.9 \%$ liquid milk samples. Abou Donia et al. (2010) found $\mathrm{Y}-\mathrm{HCH}$ in $50 \%$ of buffalo's milk samples. The presence of $\Upsilon$ $\mathrm{HCH}$ (lindane) in contaminated samples in the present study is consider serious problem, as it is 
carcinogenic in nature, and may affect the functioning of other vital organs of the body (Vettorazzi, 1975). Endosulfan is generally assumed to be not passing into milk. So, the most of the monitoring studies of milk and milk products in respect of OCP residues have not reported occurrence of residues of Endosulfan excepting that of Darko and Acquaah, (2008) and Nag and Raikwar, (2008) who reported the presence of Endosulfan in dairy products in Ghana and India, respectively.

Higher level of pp' DDE were detected in milk in china (Zhong et al., 2003) who reported that mean concentration of $\mathrm{pp}^{\prime}$ DDE in examined milk samples was 0.038 while lower level of pp' DDE were detected in Ghana (Darko and Acquaah, 2008) who reported that mean concentration was $0.001 \mathrm{ppm}$.

Heptachlor was not detected in the present study, while Salem et al. (2009) reported that heptachlor was detected in two milk samples with mean concentration of $0.026 \mathrm{mg} / \mathrm{kg}$ fat and its MRL according to (FAO/WHO, 2006) which $0.006 \mathrm{mg} / \mathrm{kg}$ fat was exceeded in both samples. John et al. (2001) found heptachlor residue in buffalo's milk samples at a level of $0.15 \mathrm{ppm}$ which also exceeded the tolerance limit. Abou Donia et al. (2010) detected heptachlor and $\mathrm{H}$. epoxide in $8.3 \%$ and $25 \%$ buffalo's milk samples with a mean values of 0.032 and $0.064 \mathrm{ppm}$ fat basis respectively, that is exceeded MRLs.

Endrin insecticide is rapidly metabolized to dieldrine in animals, (Smith, 1991). Therefore, the total residues of both endrin and dieldrin insecticides were considered as total dieldrin. The levels of Dieldrin measured in the present study were lower than those reported in a study conducted in Giza, Egypt, in which the mean concentration of Dieldrin in raw milk was $2.966 \pm 0.135 \mathrm{mg} / \mathrm{kg}$ and the frequency was $55.5 \%$ (Ahmed and Zaki, 2009). On the contrary, Salem et al. (2009) detected no Dieldrin residues in milk sampled in Jordan. Endrin in the present study was not detected in any examined milk samples due to the limited use of these insecticides.

Organochlorine pesticides pose serious risk to human health and the environment, which may include carcinogenicity, reproductive impairment, developmental and immune system changes and endocrine disruption (IOMC, 2002). The existence of OCP residues in milk with concentrations over than their corresponding MRLs will set off the alarm bell.

Table 2 and Fig 3, showed the presence of pyrethroid pesticide residues in collecting milk samples. Cypermethrin, deltamethrin, Fenvaluate, Lambda_cyhalothrin and Permethrin were monitored in milk samples while, Fenopropathrin was not monitored. The frequency distribution and mean residue levels of these pesticide in milk samples were as follows cypermethrin $(60 \%) 0.0253 \mathrm{ppm}$, deltamethrin (40\%) 0.0417 ppm, Fenvaluate (50\%)
0.0242 ppm, Lambda_cyhalothrin (56.7\%) 0.0156 ppm and permethrin (60\%) 0.0263 ppm. Fenopropathrin were not detected in all examined milk samples.

The cypermethrin concentrations that found in milk samples were not exceeded the limits of FAO/WHO and EU. Increase concentration of Cypermethrin may cause adverse health impacts While, residue levels of permethrin were above these limits.

Currently, synthetic pyrethroids are extensively and frequently used because they are effective against different pests in agriculture, livestock and public health purposes. They have selective toxicity towards insects as well as their low toxicity to mammals and animals comparing with OCPs and OPPs (Kidd and James, 1991). Cypermethrin, is classified as restricted pesticide by EPA because its toxicity to fish, but in Egypt, it is still used to control a broad spectrum of pests in agriculture and veterinary sectors. Also, it is used to Pesticidescontrol the pests at home and buildings (Extoxnet, 1996).

Table 3 revealed that the mean concentration of Diazinon and Chlopyrifos were 0.0183 and 0.310 $\mathrm{mg} / \mathrm{kg}$ in milk samples with incidence rate 100 and $3.3 \%$, respectively. While, other organophosphorus insecticide such Malathion, phorateEthion, dimethoate, primiphosmethyle were not detected. Our results were disagreeing with Fagnani et al. (2011).Who detected malathion in milk at a mean concentration of $0.02 \mathrm{mg} / \mathrm{kg}$ and a positive frequency of $8.33 \%$. Also, disagree with (Shaker and Elsharkawy, 2015). Who they detect that the mean concentration of Malathion in the analyzed milk samples was $0.195 \mathrm{mg} / \mathrm{kg}$. The main sources of pesticide residues in milk samples are contaminated feed, grass or corn silage, and direct application of pesticides on dairy cattle in barns or dairy plants. (Johansen et al., 2004).

\section{CONCLUSION AND RECOMMENDATION}

From the obtained results, it could be concluded that OC, Pyrethroid, and OP residues were detected in examined raw milk samples. Some detected values of pesticides residues were exceeded the maximum residues limits of FAO/WHO and EU. The risk of using pesticides especially OC pesticides on human health was associated with cancers and increased risk of Alzheimer disease (Singh et al., 2013), so the main management tool is the prevention of exposure either through feed or from animal environment as well as application of withdrawal time (Kan and Meijer, 2007), and monitoring the pesticides residues continuously in milk is very essential to safeguard the consumer health and achieve the food safety.

\section{REFERENCES}

Abou Donia, M.A.; Abou-Arab, A.A.K.; Enb, A.; El Senaity, M.H. and Abd Rabou, N.S. (2010): 
Chemical composition of raw milk and the accumulation of pesticide residues in milk products. Global Vet. 4 (1), 06-14.

Ahmed; N.S. and Zaki, E.M.S. (2009): Detection of some organochlorine pesticides in raw milk in Giza governorate. J. Appl. Sci. Res.5: 25202523.

Akhtar, M.W.; Sengupta, D. and Chowdhury, A. (2009): Impact of pesticides use in agriculture: their benefits and hazards. Interdisciplinary Toxicol 2: 1-12.

Battu, R.S.; Singh, B. and Kang, B.K. (2004): Contamination of liquid milk and butter with pesticide residues in the Ludhiana district of Punjab state, India. Ecotoxicol. Environ. safety 59: 324-331.

Borga, K.; Gabrielsen, G.W. and Skaare, J.U. (2001): Biomagnification of organochlorines along a Barents Sea food chain. Environ Pollut 113(2): 187-198.

Darko, G. and Acquaah, S.O. (2008): Levels of organochlorine pesticides residues in dairy products in Kumasi, Ghana. Chemosphere71, 294-298.

EUEuropean Commission (2007): DG Health and Consumer Protection, Draft Annexes to Regulation 396/2005: Annex I, II, III and IV.

European Union (EU) (2014): MRLs of pesticides, available at http://ec.europa.eu/sanco pesticides/public/?event=homepageExtoxnet

(Extension Toxicology Network Pesticide Information Profiles) (1996): http://extoxnet. orst.edu/pips/cypermet.htm.

Fagnani, R.; Beloti, V.; Battaglini, A.P.P.; Dunga, K.S. and Tamanini, $R$. (2011): Organophosphorus and carbamates residues in milk and feedstuff supplied to dairy cattle. Pesq Vet. Bras 31(7): 598-602.

Falandysz, J.; Wyrzkowska, B.; Warzocha, J.; Barska, I. and Garbacik Wesolowska, A. (2004): Organochlorine pesticides and PCBs in perch Percafluviatilis from the Odra/Oder river estuary, Baltic sea. Food Chem 87(1): 17-23.

FAO/WHO (Food and Agriculture Organization/ World Health Organization) (2013): Codex Maximum Residue Limits for Pesticide Residues in Food, updated on 2013, available at http://www.codexalimentarius. net/pestres/ data/in dex.html.

FAO/WHO (2006): Codex Maximum limits for pesticides residues. Rome: Codex Alimentarius Commission, FAO and WHO.

Fontcuberta, M.; Arques, J.F.; Villaalbi, J.R.; Martinez, M.; Centrich, F.; Serrahima, E.; Pineda, L.; Duran, J. and Casas, C. (2008): Chlorinated organic pesticides in marketed food: Barcelona, 2001-2006. Science of the total Envirnoment: 389: 52-57.

IOMC (Inter-Organization program for the sound Management of Chemicals) (2002): Persistent
Organic Pollutants Assessment report. Geneva, Switzerland: WHO.

Johansen, P.; Muir, D.; Asmund, G. and Riget, F. (2004): Human exposure to contaminants in the traditional Greenland diet. Sci Total Environ 331(1-3): 189-206.

John, P.J.; Bakore, N. and Bhatnagar, P. (2001): Assessment of organochlorine pesticide residue levels in dairy milk and buffalo milk from Jaipur City, Rajasthan, India. Environ. Int. 26: 231-236.

Kampire, E.; Kiremire, B.T.; Nyanzi, S.A and Kishimba, M. (2011): Organochlorine pesticide in fresh and pasteurized cow's milk from Kampala markets. Chemosphere 84(7): 923927.

Kan, C.A. and Meijer, G.A.L. (2007): The risk of contamination of food with toxic substances present in animal feed. Anim. Feed Sci. Technol. 133:84-108.

Kidd, H. and James, D.R. (1991): The agrochemical Handbook. The royal Society of Chemistry. Cambridge, 3rd ed.

Lampert, L.M. (1975): Modern Dairy Products. 3rd Ed., Chemical Publishing Co., Inc., New York.

Ledoux, M. (2011): Analytical methods applied to the determination of pesticide residues in foods of animal origin. A review of the past two decades. Journal of Chromatography A, 1218: 1021-1036.

Lehotay, S.J.; Mastovská, K. and Yun, S.J. (2005): Evaluation of two fast and easy methods for pesticide residue analysis in fatty food matrices. J. AOAC Int 88(2): 630-638.19.

Nag, S.K. and Raikwar, M.K. (2008): Organochlorine pesticides residues in bovine milk. Environ. Contam. Toxicol.80, 5-9.

Salem, M.N.; Rafat, A. and Hussein, E. (2009): Organochlorine pesticides residues in dairy products in Jordan. Chemosphere 77, 673-678.

Shaker, E.M. and Elsharkawy, E.E. (2015): Organochlorine and Organophosphorus Pesticide Residues in Raw Buffalo Milk from Agroindustrial areas in Assiut, Egypt. Journal of Dairy, Veterinary and Animal Research 2(5): 00049.

Singh, N.; Chhillar, N.; Banerjee, B.; Bala, K.; Basu, M. and Mustafa, M. (2013): Organochlorine pesticide levels and risk of Alzheimer's disease in north Indian population. Hum. Exp. Toxicol. 32(1): 24-30.

Smith, A.G. (1991): Classes of pesticides. In: Hays, W.J., Law, E.R. (Eds.), Handbook of Pesticides Toxicology, vol. 2. Academic Press, San Diego, CA, pp. 824e827.

Vettorazzi, G. (1975): State of the toxicological evaluation carried out by the Joint FAO/WHO Expert Committee on pesticide residues. I. Organohalogenated pesticides used in public health and agriculture. Residue Rev. 56: 107134. 


\section{الكثف عن بعض متبقيات المبيدات الحشرية فى اللبن الخام}

\section{محد سعبل الاسبيوطي ، فايزة عبل العزيز التداوى ، أمانس عبد الرحمن سلام ، فايزة أحد صديق}

Email: mido_15158@hotmail.com Assiut University web-site: $\underline{\text { www.aun.edu.eg }}$

نظر الكثرة إستخدام للمبيدات الحشرية فى الاونة الاخيرة في مقاومة الافات الزر اعية و الطفيليات الخارجية الناقلة للامر اض المختلفة

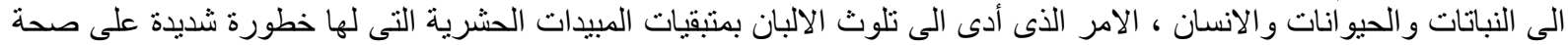

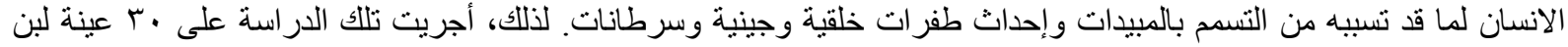

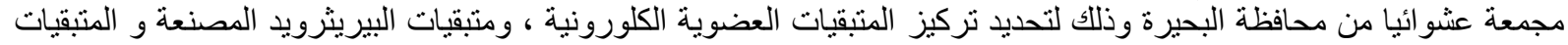

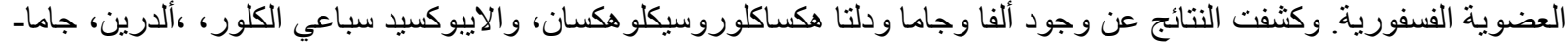

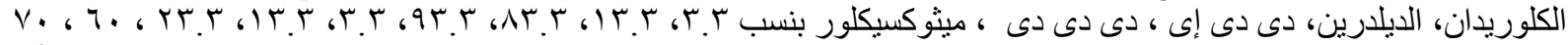

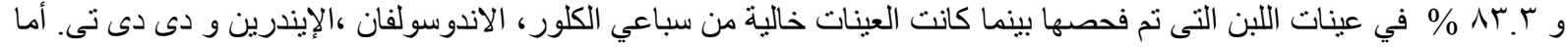

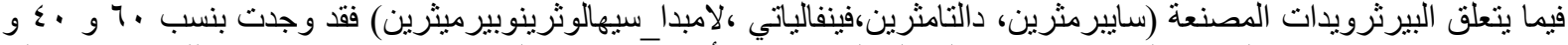

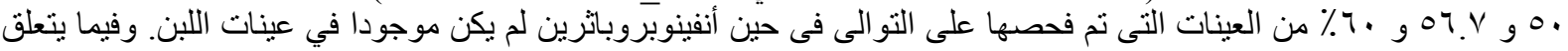

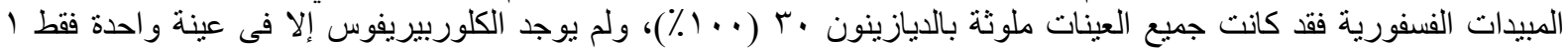

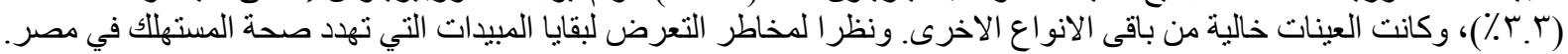

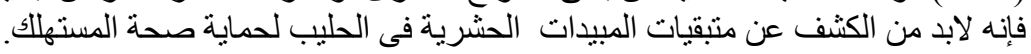

